\title{
Antifascism in the Neighborhood: Daily Life, Political Culture, and Gender Politics in the German Communist Antifascist Movement, 1930-1933
}

\author{
Sara Ann Sewell \\ Department of History, Virginia Wesleyan University, Virginia Beach, USA \\ ssewell@vwu.edu
}

\begin{abstract}
This article examines grassroots communist antifascist politics in Germany during the final years of the Weimar Republic. In contrast to most studies on Weimar's street politics, which focus on political violence, this research demonstrates that daily life, political culture, and gender relations shaped the communist antifascist movement in working-class neighborhoods. It argues that daily conflict with distinct political overtones or undertones increased steadily in the early 1930s. As a result, quarrels between neighbors were often colored with political narratives, and sometimes ordinary disputes escalated into political conflict and even violence. Political culture inflamed the tensions, particularly when Nazis and communists littered proletarian boroughs with their symbols. Women were often at the center of the conflict. Many joined the frontlines of communist antifascist struggle, where they faced widespread discrimination from male comrades who, flaunting a militant hypermasculinity, insisted that women belonged only in the rearguard.
\end{abstract}

\section{Keywords}

Germany - Weimar Republic - antifascism - communism - daily life - gender women - political violence

The year 1929 marked a pivotal moment in the Weimar Republic. On the diplomatic front, Germany renegotiated the Versailles Treaty, settling on the Young Plan, which reduced reparations and laid the groundwork for the evacuation of

(C) SARA ANN SEWELL, 2020 | DOI:10.1163/22116257-20201175

This is an open access article distributed under the terms of the prevailing CC-BY-NC license at the time of publication. 
French troops from the Rhineland. On the national scene, Germany mourned Foreign Minister Gustav Streseman, who suffered a stroke in October after brokering the Young Plan. Social crises mounted steadily in spring 1929, culminating in May in a three-day insurrection in Berlin. Finally, the international economy suffered a major blow in October when the US stock market crashed. These events left an indelible imprint on German domestic politics, for each contributed to the radicalization of the populace, which could be gauged by the 14 September 1930 Reichstag elections when both the Kommunistische Partei Deutschlands [KPD: German Communist Party] and the Nationalsozialistische Deutsche Arbeiter Partei [NSDAP; National Socialist German Workers' Party] scored historic successes. The KPD captured thirteen percent of the electorate, and the NSDAP won eighteen percent.

This article examines grassroots politics in the aftermath of 1929, specifically the communist antifascist movement, as a framework to study the politicization of communists and sympathizers. With the NSDAP's remarkable electoral success, National Socialists became potent political foes, challenging communists at the ballot box, in the workplace, and on the streets. The KPD responded by launching an antifascist movement. The popularity of Nazism and the communist rebuttal fundamentally altered daily life in working-class neighborhoods. Since Eve Rosenhaft's seminal study on political violence in Berlin's proletarian boroughs, a number of scholars have investigated the violence of the early 1930s. ${ }^{1}$ At times, the violence was endemic, particularly in summer 1932 when nearly every day registered dead and wounded across the country. Conflict, however, was more pervasive than the tally of nightly brawls indicated. A comprehensive examination of antifascist activities shows that daily life, political culture, and gender relations all contributed to the growing tensions in working-class neighborhoods.

Communists were hardly alone in confronting Nazis. Supporters of the Sozialdemokratische Partei Deutschlands [SPD: German Social Democratic Party] also mobilized after the 1930 Reichstag elections. ${ }^{2}$ Many took to the

Eve Rosenhaft, Beating the Fascists? The German Communists and Political Violence, 1929-1933 (New York: Cambridge UP, 1983). See also Anthony McElligott, Contested City: Municipal Politics and the Rise of Nazism in Altona, 1917-1937 (Ann Arbor: University of Michigan Press, 1998); Dirk Schumann, Political Violence in the Weimar Republic, 1918-1933: Battle for the Streets and Fears of Civil War (New York: Berghahn, 2009); Christian Striefler, Kampf um die Macht: Kommunisten und Nationalsozialisten am Ende der Weimarer Republik (Berlin: Propyläen, 1993); Carsten Voigt, Kampfbünde der Arbeiterbewegung: Das Reichsbanner Schwarz-Rot-Gold und der Rote Frontkämpferbund in Sachsen 1924-1933 (Cologne: Böhlau, 2009).

2 Roger Philip Chickering, 'The Reichsbanner and the Weimar Republic, 1924-26,' The Journal of Modern History 40, no. 4 (1968): 524-534; Donna Harsch, German Social 
streets under the auspices of the SPD's Reichsbanner. With a membership of three million, the Reichsbanner was Germany's largest paramilitary force, and it was the most vocal SPD organization to call for a militant antifascist response. Other social democrats enlisted in the Eiserne Front [Iron Front], a defense league that was established in December 1931 by the SPD and the Allgemeiner Deutscher Gewerkschaftsbund [ADGB; General German Trade Union Confederation] to counter both Nazism and communism. ${ }^{3}$ In their antifascist activities, social democrats engaged in propaganda work, electioneering, demonstrations, and physical struggle. While they sometimes battled communists, on the ground many called for joint action against the Nazis. ${ }^{4}$ The picture that thus emerged was one of social democrats, communists, and Nazis participating in a wide range of street actions. By 1931, Germany's working-class neighborhoods had become overtly politicized with all groups boldly strutting their politics in ways that profoundly altered everyday life, from marching in demonstrations decked out in political insignia, to hanging banners from their apartment windows, to yelling militant slogans as they marched through neighborhoods, to battling foes over local turf, to murdering enemies.

This examination of the communist antifascist movement is informed by Klaus-Michael Mallmann's research on communists in the Saarland. Situating communist politics within working-class communities or 'left-proletarian milieus', Mallmann gives a prominent voice to those beyond the KPD's 'avantgarde', arguing that at the grassroots level, communists operated with considerable autonomy, resisting party directives when they found them to be contrary to their realities on the ground. ${ }^{5}$ This interpretation challenges an older historiography, advanced foremost by Hermann Weber, which asserts that KPD leaders, heeding Kremlin directives, enacted a process of 'Stalinization' whereby they silenced party dissent and created a cadre of 'obedient soldiers. ${ }^{6}$ Shifting from institutional politics to grassroots politics, Mallmann countered that 'the interpretation of communism as a monolithic, one-dimensionally defined system ... misunderstands that members were primarily subjects who formed their politics on the ground ... ignoring instructions from above when they held them to be false. ${ }^{7}$

Democracy and the Rise of Nazism (Chapel Hill: University of North Carolina Press, 1993), 102-105; Voigt, Kampfbünde der Arbeiterbewegung, 97-108, 127-141.

3 Harsch, German Social Democracy, 169-202.

4 Ibid., 196-198.

$5 \quad$ Klaus-Michael Mallmann, Kommunisten in der Weimarer Republik: Sozialgeschichte einer revolutionären Bewegung (Darmstadt: Wissenschaftliche Buchgesellschaft, 1996).

$6 \quad$ Hermann Weber, Die Wandlung des deutschen Kommunismus: Die Stalinisierung der KPD in der Weimarer Republik, 2 vols. (Frankfurt/M: Europäische Verlagsanstalt, 1969). 
Mallmann's monograph ignited a strident historiographical debate, centered on the question of whether communists toed the party line. In Andreas Wirsching's view, Mallmann underestimates the KPD's coercive methods and the Soviets' role in directing the KPD, which began with the issuing of the Comintern's 'Twenty-One Conditions' in 1919/20. ${ }^{8}$ Despite his unyielding critique, Wirsching convincingly points out that Mallmann downplays the ways that the KPD did cultivate a party culture that extolled discipline. From the perspective of institutional politics, abundant evidence exists to demonstrate that KPD leaders doggedly sought loyalty. The numerous expulsions alone provide sufficient proof of the measures leaders took to induce loyalty, albeit not very successfully. This political narrative is buttressed by a cultural analysis. When the communist movement is examined through a cultural lens, the uniformity of the KPD's rhetorical arsenal was undeniable. The same rituals, symbols, and languages appeared and reappeared, and the performance of these ritualistic acts was decisive for cultivating a disciplined political community.

Mallmann's questioning of the KPD's totalitarian features, nevertheless, has merit. In fact, party documents are replete with reports of members disregarding edicts. At the grassroots level, political fidelity was uneven, for supporters appropriated political positions and practices in ways that made sense to them on the ground. This was particularly true regarding antifascist violence. While the KPD advocated mass action and ordered its cadre to avoid battling Nazis, at the grassroots level, many activists disregarded these directives, particularly when they perceived that conditions in their neighborhoods necessitated immediate action. An analysis of gender relations within the antifascist movement similarly demonstrates supporters' inconsistent implementation of party directives. While many activists endorsed the Party's call to welcome women as equal political actors, others resisted. This study, thus, forges a middle ground between the older historiography that stresses a heavy-handed enforcement of party discipline and the newer scholarship that emphasizes rank-and-file autonomy. ${ }^{9}$ It shows not only that party leaders did attempt to

Andreas Wirsching, "Stalinisierung" oder entideologisierte "Nischengesellschaft"? Alte Einsichten und neue Thesen zum Charakter der KPD in der Weimarer Republik,' Vierteljahrshefte für Zeitgeschichte 45, no. 3 (1997): 449-466. For Mallmann's rebuttal, see Mallmann, 'Gehorsame Parteisoldaten oder eigensinnige Akteure? Die Weimarer Kommunisten in der Kontroverse - Eine Erwiderung,' Vierteljahrshefte für Zeitgeschichte 47, no. 3 (1999): 401-415.

9 This approach is similar to that of Eric Weitz who investigates both communists' 'autonomous life-worlds and practices' and institutional KPD politics. Eric D. Weitz, Creating German Communism, 1890-1990: From Popular Protest to Socialist State (Princeton: Princeton UP, 1997), 11. 
coral supporters, but also that members and sympathizers adapted or resisted directives, particularly when they belied realities on the ground.

To investigate the communist antifascist movement from activists' perspective, this research relies upon the writings of rank-and-file communists and sympathizers. Beginning in 1924, the KPD solicited workers to pen articles about their everyday lives. Known as 'worker correspondents', these writers submitted articles on a wide range of topics to the party press. ${ }^{10}$ Simultaneously, the KPD organized itself into factory and neighborhood cells, many of which published cell papers. KPD leaders instrumentalized the Worker Correspondent Movement and cell papers to integrate followers into party work. The writers were to serve as megaphones for the KPD by linking everyday issues to party platforms. KPD dailies regularly published a section entitled 'From the Lives of Workers', which featured a series of individual worker correspondences that were accompanied by an editor's analysis and the latest party slogans. Cell papers were similarly influenced by KPD leaders. A careful perusal of cell papers shows that many printed not only the same slogans but also the same artwork, demonstrating some success at 'Bolshevizing' the cadre.

Situated at the nexus of party organization and everyday life, worker correspondents and cell paper authors offer unique insight into the historiographical debate regarding Weber's Stalinization Thesis. As noted above, party leaders implored supporters to pen articles as a strategy to tie followers to party organization. However, the benefits the KPD reaped from worker correspondences and cell papers were ephemeral, for these writings were published largely erratically. In fact, most of the authors submitted only a single report and never joined the Party. It would, therefore, be short-sighted to dismiss the writers as the pawns of party leaders. Indeed, a close reading of these sources reveals instances of both editorial heavy-handedness and authorial independence. This is especially true for cell papers, which were largely amateurish publications due to the fact that the KPD did not possess the staff to oversee them. But it was precisely this lack of editorial oversight that provided cells with the autonomy to tailor the papers to their own interests, such as complaining about dirty beer glasses in the work cafeteria. ${ }^{11}$ This body of sources, thus,

$10 \quad$ Christa Hempel-Küter, Die kommunistische Presse und die Arbeiterkorrespondentenbewegung in der Weimarer Republik: Das Beispiel der 'Hamburger Volkszeitung' (Frankfurt am Main: Lang, 1989); Gerhard Moser, 'Zwischen Autonomie und Organisation: Die Arbeiterkorrespondenten-bewegung der "Roten Fahne" in den Jahren 1924 bis 1933' (PhD. diss., University of Vienna, 1988); Brendan Simms, 'The Workers Correspondents' Movement in Württemberg during the Weimar Republic: 1928-1933,' European History Quarterly 21, no. 4 (1991): 481-514. 
presents a more complex picture of grassroots communism than viewed from above. Although certainly influenced by party platforms and edicts, these writers were not simply sloganeers for the KPD, for daily life also shaped their politics, and in many cases, it was the experiences of everyday life that prompted them to pick up a pen.

This investigation of the communist antifascist movement at the intersection of everyday life, political culture, and gender relations in proletarian districts demonstrates that the politicization of the ordinary was a defining feature of the late Weimar polity. Historians disagree as to whether the political violence should be characterized as an everyday experience. ${ }^{12}$ While the most severe violence did ebb and flow in the early 1930s, daily conflict with distinct political overtones or undertones increased steadily during those same years. Indeed, mundane arguments between neighbors routinely escalated into political conflict and at times into brutal clashes. Although most disagreements did not lead to physical struggle, the disputes did contribute to an atmosphere of rising tensions that periodically escalated into violence. In this context, fascist and antifascist political cultures were especially incendiary. Particularly when deployed in everyday terrains, political symbols, rituals, and languages contributed to interpersonal friction. Gender relations likewise fueled conflict. While the violence was chiefly a masculine political exercise, women also figured prominently in the conflict. However, as they mounted the barricades, antifascist women faced widespread discrimination from male comrades who, defying KPD directives and flaunting a militant hypermasculinity, insisted that women belonged only in the antifascist rearguard.

\section{Founding the Communist Antifascist Movement}

The seeds for establishing the communist antifascist movement were planted in 1929 after a three-day insurrection in Berlin. On May Day, protesters took to the streets in defiance of a ban on open-air demonstrations. Within hours, the protests morphed into full-fledge revolts in working-class districts, marking the fiercest street fighting in Berlin since 1919. Police responded with substantial force, which left approximately 33 dead and 198 wounded. ${ }^{13}$ Of the dead,

While Dirk Schumann argues that political violence was not 'an everyday phenomenon', Anthony McElligott contends that it was. Schumann, Political Violence, 267; McElligott, Contested City, 182. 
only one was a KPD member, and of the 1,200 arrested, 119 were identified as communists by the police. ${ }^{14}$ The KPD faced a crackdown after the insurgency. Most significantly, on 3 May 1929, the KPD's paramilitary organization, the Rotfrontkämpferbund [RFB; Red Front Fighting League], its insignia, and its 'Red Front' salute with its iconic raised, clenched fist, were banned..$^{15}$ This was pivotal to the KPD's establishment of its antifascist movement, which provided an outlet for the outlawed paramilitary squadron. Communists immediately began to convene antifascist committees and demonstrations, but throughout 1929 and 1930, the movement remained marginal. ${ }^{16}$ The Nazis' success in the September 1930 Reichstag elections, however, prompted the KPD to take more concerted steps to organize. Only days later, it founded the Kampfbund gegen den Faschismus [Fighting League against Fascism]. ${ }^{17}$ In the context of a surge in Nazi activity in 1931 and 1932, the KPD also established the

und Kommunisten im Brennpunkt der Berliner Ereignisse von 1929 (Bonn: Dietz, 1988); Peter Lessmann-Faust, “Bloody May”: The Case of Berlin 1929,' in Patterns of Provocation: Police and Public Disorder, ed. Richard Bessel and Clive Emsley (New York: Berghahn, 1998), 11-27; Léon Schirmann, Blutmai Berlin 1929: Dichtungen und Wahrheit (Berlin: Dietz, 1991); Pamela E. Swett, Neighbors and Enemies: The Culture of Radicalism in Berlin, 1929-1933 (Cambridge: Cambridge UP, 2004), 120-130. Lessmann-Faust, "Bloody May", 12; Swett, Neighbors and Enemies, 126. Kurt Finker, Geschichte des Roten Frontkämpferbundes (Berlin: Dietz, 1981), 190-202; Mallmann, Kommunisten, 194-195; Kurt Schuster, Der Rote Frontkämpferbund 19241929: Beiträge zur Geschichte und Organisationsstruktur eines politischen Kampfbundes (Düsseldorf: Droste, 1975), 193-238.

16 On the KPD's antifascist movement, see Werner Bramke, 'Die Bündnispolitik der KPD im Rahmen des antifaschistischen Massenkampfes in den Jahre der Weltwirtschaftskrise,' Beiträge zur Geschichte der Arbeiterbewegung 22, no. 5 (1980): 669-685; Edgar Doehler, 'Zur Rolle des wehrhaften antifaschistischen Kampfes in der Politik der KPD (1929-1933),' Militärgeschichte 17, no. 5 (1978): 534-541; Kurt Finker, 'KPD und Antifaschismus 1929 bis 1934,' Zeitschrift für Geschichtswissenschaft 41, no. 5 (1993): 389-398; Andreas Wirsching, 'Kommunistischer "Antifaschismus" in Berlin und Paris zwischen den Weltkriegen,' in Anpassung, Verweigerung und Widerstand: Soziale Milieus, Politische Kultur und der Widerstand gegen den Nationalsozialismus in Deutschland im regionalen Vergleich, ed. Detlef Schmiechen-Ackermann (Berlin: Hentrich, 1997), 201-220.

'Organisationsrichtlinien für die Aufbau und die Aufgabe des Kampfbundes gegen den Faschismus,' Berlin, 10 October 1930, Stiftung Archiv der Parteien und Massenorganisationen der ehemaligen DDR im Bundesarchiv, Zentrales Parteiarchiv (hereafter SAPMO-BA): RY1 I 4/9/3. On the establishment of the Fighting League, see Conan Fischer, The German Communists and the Rise of Nazism (New York: St. Martin's Press, 1991), 145-159; Rosenhaft, Beating the Fascists? 92-96; James J. Ward, "Smash the Fascists..." German Communist Efforts to Counter the Nazis, 1930-31,' Central European History 14, no. 1 (1981): 55-56; Schumann, Political Violence, 231-232. 
Roter Massenselbstschutz [RMss; Red Mass Self-Defense] in late 1931 and the Antifaschistische Aktion [Antifascist Action] in May 1932. ${ }^{18}$

The KPD's foremost objective for its antifascist organizations was to challenge National Socialism through mass protest. Activists were charged with an array of propaganda work, such as hosting factory and neighborhood meetings, selling literature, and conducting door-to-door campaigns. Their most important task was organizing demonstrations. From small towns to large cities, communists held regular demonstrations, sometimes even when open-air rallies were prohibited. These gatherings were intended to counter the Nazis' growing popularity and to spur sympathizers to action. By 1932, antifascist protests took place nearly every week. In smaller cities, they usually attracted about one hundred people; other demonstrations were massive, such as the one in Berlin on 3 July 1932, which Die Rote Fahne reported assembled over 100,00o. ${ }^{19}$

The antifascist organizations' second cardinal mission was to build a mass movement by recruiting sympathizers, as expressed by one cell paper: 'We are calling on Christian and social democratic workers: Come to us and fight with us against fascism. The new Fighting League is not a Communist Party organization, but an organization of the broadest fighting united front of the working people!'20 The KPD touted its antifascist groups as 'above-party', 'united-frontfrom-below' organizations to unite the working-class masses in a common struggle against fascism. Nevertheless, most activists did not join a KPD antifascist organization. ${ }^{21}$

On the RMss, see 'Richtlinien für Roten Massenselbstschutz,' n.d. (c.1932), sAPMoвА: RY1 I 4/9/1; Kampfbund gegen den Faschismus, Rundschreiben, no. 6, 29 June 1932, SAPMO-BA: RY1 I 4/9/4; 'Richtlinien für den Aufbau des Roten Massenselbstschutzes,' n.d. (c. 1932), SAPMO-BA: RY1 I 4/9/4. On the Antifascist Action, see 'Richtlinien zur Schaffung der Antifaschistischen Aktion,' n.d. (c. 1932), SAPMO-BA: RY1 I 2/8/5; 'Manifest der Antifaschistischen Aktion,' Die Rote Fahne, 12 July 1932. See also Ben Fowkes, Communism in Germany under the Weimar Republic (New York: St. Martin's Press, 1984), 166-171; Mallmann, Kommunisten, 365-380; Rosenhaft, Beating the Fascists? 97-100; Carsten Voigt, 'Die Antifaschistische Aktion 1932 in Sachsen an Der Basis Der Arbeiterparteien: Gemeinsamkeiten und Brüche', Jahrbuch für Forschungen zur Geschichte der Arbeiterbewegung 3 (2007): 122-133; Voigt, Kampfbünde der Arbeiterbewegung, 541-549. 'Ueber 100,00o Kämpfer marschieren unter dem Banner der Antifaschistischen Aktion!' Die Rote Fahne, 5 July 1932.

'Kämpft mit der KPD für ein Sowjet-Deutschland!' Die Rote Straße: Häuserblockzeitung (Cologne-Kalk) 2, no. 2 (October 1930).

In December 1931, the Fighting League registered 106,ooo members. 'Mitgliederbewegung des Kampfbundes gegen den Faschismus (1931),' 1932, SAPMO-BA: RY1 I 4/9/3. Hermann 
Similar to the KPD's other attempts to forge a 'united front from below', the antifascist organizations were intended to drive a wedge between the members and leaders of other labor groups, particularly the SPD. Before World War One, many communists had belonged to the SPD, but antipathy between the former comrades steadily increased after their split in $1917 .{ }^{22}$ Founded in the final days 1918, the KPD was to represent a revolutionary alternative to the SPD. For communists, the break became irrevocable in January 1919 when the KPD's leaders, Rosa Luxemburg and Karl Liebknecht, were assassinated. Communists pinned the murders on the SPD brass, and thereafter, they relentlessly inveighed against the SPD leadership. The Comintern's 1928 'Third Period' doctrine, which portended a severe economic crisis that would create revolutionary conditions, unleashed a new wave of attacks. ${ }^{23}$ Following Moscow's cues, the KPD charged that the SPD concealed its fascist-capitalist agenda, which rendered the SPD more dangerous than the NSDAP. As Die Rote Fahne pronounced, social democracy was 'socialism in words, fascism in deeds. ${ }^{24}$

The ideological divide between the SPD and the KPD did not deter communists from attempting to recruit social democrats to their antifascist banner by

Weber cites March $193^{1}$ with the highest membership of 110,0oo. Weber, Die Wandlung, vol. 1, 364-365. Thereafter, the organization experienced a precipitous decline, bottoming out at 32,00o members in January 1932. Rosenhaft, Beating the Fascists? 94-95.

There is a vast literature that details the fragmentation of the SPD. Georg Fülberth, Die Beziehung zwischen SPD und KPD in der Kommunal Politik der Weimarer Periode 1918/19 bis 1933 (Cologne: Pahl-Rugenstern, 1985); Joachim C. Häberlen, 'Kameradschaft mit dem Messer? Zum Zerfall des linksproletarischen Milieus in Leipzig am Ende der Weimarer Republik,' Archiv für Sozialgeschichte 53 (2013): 223-243; Häberlen, 'Klassenkampf an allen Fronten oder politische Belästigung? Umstrittene Räume des Politischen innerhalb der Leipziger Arbeiterbewegung am Ende der Weimarer Republik,' Werkstatt Geschichte 59 (2012): 79-91; Carl E. Schorske, German Social Democracy, 1905-1917: The Development of the Great Schism (Cambridge: Harvard University Press, 1983).

23 On the 'Third Period' in Germany, see Nicholas N. Kozlov and Eric D. Weitz, 'Reflections on the Origins of the "Third Period": Bukharin, the Comintern and the Political Economy of Weimar Germany,' Journal of Contemporary History 24 (1989), 387-410; Norman LaPorte, German Communist Party in Saxony, 1924-1933 (New York: Peter Lang, 2003), 237-298; Hermann Weber, Hauptfeind Sozialdemokratie: Strategie und Taktik der KPD 1929-33 (Dusseldorf: Dorste, 1982).

24 'Der bewaffnete Sozialfaschismus,' Die Rote Fahne, 8 August 1929. See Siegfried Bahne, 'Sozialfaschismus in Deutschland": Zur Geschichte eines Politischen Begriffs,' International Review of Social History 10, no. 2 (1965): 211-245; Fowkes, Communism in Germany, 153-166; LaPorte, The German Communist Party, 237-298; Rosenhaft, Beating the Fascists? 29-37; James Wickham, 'Social Fascism and the Division of the Working Class Movement: Workers and Political Parties in the Frankfurt Area 1929-1930', Capital and Class, no. 7 (1979), 1-34; Wirsching, 'Kommunistischer "Antifaschismus"', 209-213. 
excoriating SPD and union leaders. 'Social democratic and Christian workers ... What have your leaders done to prevent the fascist terror?' the KPD leadership rhetorically posed. 'Nothing! [Y] our leaders are the pioneers of fascism.'25 In fact, the KPD often devoted more energy to attacking the SPD than the NSDAP, a strategy that culminated in the 'Red Referendum' of August 1931 when the KPD aligned with Nazis and nationalists in a futile effort to bring down the SPDled government in Prussia. Despite the enmity between communists and social democrats, there were instances when they joined together against Nazism, particularly at the grassroots level, for many social democrats 'yearned for unity' in their antifascist struggle, as Donna Harsch maintains. ${ }^{26}$

\section{Antifascism in the Neighborhood}

Communist antifascist organizations were intended to serve as neighborhood watch groups. ${ }^{27}$ Given that the KPD's labor organization floundered in the wake of skyrocketing unemployment brought on by the Depression, the neighborhood increasingly became the locus of its communist work. Tensions ran high in proletarian districts, particularly when rumors of nearby Nazi activity surfaced. Cell papers cautioned neighbors that Nazis appeared 'deviously in the darkness of night to put up their lying flyers.' ${ }^{28}$ They also warned that uniformed sA men marched through neighborhoods, indiscriminately assaulting residents. ${ }^{29}$

In his influential monograph on Nazi and Italian fascist paramilitaries, Sven Reichardt asserts that SA men 'resembled invaders' in the eyes of residents in proletarian neighborhoods. ${ }^{30}$ By contrast, Eve Rosenhaft maintains that the image of SA men as menacing infiltrators was largely the work of KPD propaganda. ${ }^{31}$ Whether real or merely propaganda, Nazis were painted as community outsiders. Upon hearing that Nazis were closing in on their neighborhoods,

KPD, Bezirksleitung Mittle Rhein, 'Verteidigung des Arbeiterlebens,' Sozialistische Republik, 2-3 July 1932.

26 Harsch, German Social Democracy, 103.

27 'Richtlinien für den Aufbau des Roten Massenselbstschutzes.'; Fritz Lange, 'Bericht über den Kampfbund gegen den Faschismus,' 28 January 1931, SAPMO-BA: RY1 I 4/9/3.

28 'Nacht = Gestalten,' Der Späher: Organ der Kommunistischen Gemeinde-Fraktion in Lauter, no. 11 (January 1931).

29 Die Bergheimer Frau (Duisburg), 1930; 'Mehrere Parteilose aus der Hagelberger Strasse,' Fackel: Organ der Werktätigen vom Kreuzberg, February 1932.

30 Sven Reichardt, Faschistische Kampfbünde: Gewalt und Gemeinschaft im italienischen Squadrismus und in der deutschen SA (Cologne: Böhlau Verlag, 2002), 117.

$31 \quad$ Rosenhaft, Beating the Fascists? 61; Reichardt, Faschistische Kampfbünde, 117. 
activists regularly assembled to confront them. Such was the case in CologneKalk in January 1931 when, according to a working correspondent, residents participated in a 'spontaneous' demonstration, successfully confronting Nazis who were marching into the borough. The writer defiantly declared, 'Kalk is red and will remain red. ${ }^{32}$ Such proclamations highlighted several key elements regarding communist antifascist strategy. First, activists viewed the battle against Nazis through the lens of the neighborhood, underscoring the localized nature of antifascist politics. While antifascists' activities were influenced by KPD politics, their neighborhoods served as their most immediate frame of reference. Second, activists did indeed characterize Nazis as external threats to working-class communities, even though the NSDAP's rolls included many workers who in some instances lived right next door to antifascists. ${ }^{33}$ Third, there was a clear proprietary dimension to antifascist defense, as activists attempted to seize political ownership of their neighborhoods. Finally, in their neighborhood defense, communists sought to leverage tightly-knit communities by appealing to neighborhood solidarity. ${ }^{34}$

To convince residents that Nazis violated the sacred bonds of the working-class community, communists employed denunciation, consistently publishing stories about Nazis' nefarious activities. Representative of such denunciations was an article about Cologne shop owner Hans Schult. According to a worker correspondent, Schult had refused to allow two men to hide from the police in his store. The author characterized Schult as a neighborhood

32 Worker Correspondent 88, 'Massenprotest gegen die braune Mordpest,' Sozialistische Republik, 26 January 1931. Worker correspondents (Arbeiterkorrespondenten) were rankand-file communists and sympathizers who wrote articles for the KPD press. In KPD organs, worker correspondents were typically assigned numbers to protect their identities, although not all worker correspondences were designated with numbers.

While workers both voted for and joined the NSDAP, historians disagree about the extent of working-class support for the Nazis. Peter Fritzsche estimates that approximately one-third of NSDAP members and voters could be classified as workers. Peter Fritzsche, Germans into Nazis (Cambridge: Harvard University Press, 1998), 201. On working-class electoral support for the NSDAP, see Jürgen W. Falter, Hitlers Wählers (Munich: Beck, 1991), esp. 199-228. Conan Fischer largely contends that communists converted to Nazism in greater numbers than Nazis enlisted in the KPD. Fischer, 'Unemployment and Left-Wing Radicalism in Weimar Germany, 1930-1933', in Unemployment and the Great Depression in Weimar Germany, ed. Peter D. Stachura (New York: St. Martin's Press, 1986), 209-225. By contrast, Francis Ludwig Carsten maintains that few former communists joined the NSDAP. F.L. Carsten, The German Workers and the Nazis (Aldershot: Scholar Press, 1995), $1-13$.

34 McElligott, Contested City, 168-169, 185-191; Rosenhaft, Beating the Fascists? 144-151; Swett, Neighbors and Enemies, 135-136, 295-296. 
traitor: 'Although Schult lives from workers' pennies [Arbeitergroschen], he is known in the neighborhood as a communist-devourer [Kommunistenfresser] . ... Not a penny more in this Nazi-store!'35 This example illustrates some essential facets about the nature of communist antifascist denunciation. Above all, activists published stories to spur neighbors to action. Often printing the names and addresses of suspected Nazis, they also attempted to localize Nazism. ${ }^{36}$ In other words, they tried to convince neighbors that the fascist danger existed right next door, despite contradictory characterizations of Nazis as outsiders. Finally, by denouncing Schult as a 'communist-devourer', this worker correspondent presumptuously and probably mistakenly conflated his neighbors' politics with his own.

In their denunciations, antifascists frequently called Nazi masculinity into question. One of their most consistent motifs was cowardliness. Using humor to appeal to neighbors, one cell paper ridiculed two Nazis who timidly hid from two workers because they were without their uniforms and fellow comrades. The cell derided the Nazis, stating that they whispered to each other, 'There's two of them, but both of us are all alone. ${ }^{37}$ Without their brothers in arms, the Nazis cowered, mocked the cell, revealing their compromised masculinity.

Antifascists also denounced Nazis as failed husbands. One worker correspondent, for instance, defamed a certain Wilhelm Schnepp who had reportedly shot a man in 1932. Publishing an exposé on Schnepp's private life, the writer claimed that Schnepp physically abused his wife and had left her twelve times. ${ }^{38}$ Devoting more ink to Schnepp's private life than his politics, the author besmirched the Nazi by stressing his spurious masculinity, suggesting that the author assumed that a rebuke of Schnepp's masculinity would resonate more with neighbors than criticism of his politics. In another example, a cell paper reported on a certain Herr Harbrink, whom it accused of accosting neighbors with a revolver in hand. To disgrace this 'legendary Christian', the cell called Harbrink's masculinity into question by painting his home as a virtual brothel. It even insinuated that Harbrink's wife had conceived of a child with a fellow Nazi. ${ }^{39}$ Impeaching Harbrink's feeble familial authority and sexual impotency, two common themes in the cuckold trope, the cell ridiculed

35 Worker Correspondent 539, 'Keinen Pfennig in dieses Nazi-Geschäft!' Sozialistische Republik, 17 August 1931.

$36 \quad$ For example, 'Massenselbstschutz verjagt Nazibanditen,' Sozialistische Republik, 7 July 1932; 'Von der "braunen Mordpest": Was parteilose Arbeiter berichten,' Sozialistische Republik, 11 July 1932.

39 'SA-Liebchen!' Arbeiter-Faust: Straßen Zeitung im Bereich der Zelle I. Köln-Süd, no. 12 (1930). 
Harbrink as a cuckold, the ultimate condition of emasculation. ${ }^{40}$ From the cell's perspective, there was a logical relationship between masculinity and the antifascist struggle. Specifically, the cell linked Harbrink's compromised masculinity, exemplified by the apparent patriarchal disorder in the fool's household, to his compromised politics.

Communist denunciations made clear that in the tense atmosphere of late Weimar, many people wrote political narratives onto the ordinary disputes of daily life. Nearly any quarrel could be filtered through a political lens. For example, in a letter published in a children's cell paper, a boy told a story of picking cherries with a friend when they were attacked by a certain Herr Suhr, 'a prominent Nazi', and his two sons. ${ }^{41}$ However, the report never clarified if the boys had been on Suhr's property, which might have justified Suhr's actions. In another incident, a worker correspondent reported on a woman who complained about a neighbor who stomped on the floor as if he were 'marching in a Nazi parade'.42 In this case, noise, a common source of discord in tenement living, was given a political reading. As such examples illustrate, communists often transposed politics onto quotidian disputes, using the label 'Nazi' indiscriminately to defame community transgressors. Indeed, in no small measure did communists stoke interpersonal conflict by coloring disputes with political narratives.

The most compelling evidence of the politicization of daily life in proletarian boroughs was the street violence. Political violence mounted steadily during the waning years of the Weimar Republic, ultimately exploding in 1932. The sites of the violence were largely working-class districts. Whether as active fighters or passersby caught in the crossfire, residents faced violence on a weekly, if not a daily, basis. ${ }^{43}$ Propaganda activities often catalyzed violence, for confrontations regularly occurred when one side was distributing literature, when activists marched through neighborhoods, or when antifascists attended Nazi meetings and vice versa. Most commonly, conflict erupted in the evening after one side had been drinking in a local pub. ${ }^{44}$

Mark I. Millington and Alison S. Sinclair, 'The Honourable Cuckold: Models of Masculine Defence,' Comparative Literature Studies 29, no. 1 (1992): 1-19.

'Ein Landkinderbrief aus Bludau,' Für unsere jüngsten Kämpfer: Kinderecke des 'Echo des Ostens', 15 August 1931.

Worker Correspondent 531, 'Wir marschieren an der Mieterfront,' Sozialistische Republik, 14 August 1931 .

From January until August 1932, fifty-six women and seven children were injured in the political skirmishes. Hans-Jürgen Arendt, 'Zur Frauenpolitik der KPD und zur Rolle der werktätigen Frauen im antifaschistischen Kampf im Frühjahr und Sommer 1932,' Beiträge zur Geschichte der Arbeiterbewegung 14 (1972): 808. 
Activists stressed that it was often the happenstances of daily life that sparked violence or threats of violence. For example, in summer $193^{2}$ a woman informed a KPD organ that a Nazi had threatened her after she had refused to relinquish her streetcar seat to a woman wearing a swastika. '[O]ne of the brown heroes rushed towards me and threatened me with a raised fist: "I will hit you right in the trap"'45 Antifascists also recounted incidents of physical assault. In a remarkable story, a cell paper from Mittweida claimed that Nazis had ambushed a family as they unwittingly passed by a Nazi house during an evening stroll. According to the cell, the Nazis dumped 'the stinking contents of a chamber pot' on them because they were not wearing swastikas. A physical altercation ensued, as five or six Nazis reportedly attacked the entire family. ${ }^{46}$ Through such tales of violence, communists sought to warn neighbors that they could be targeted by Nazis. That many such accounts highlighted women as victims underscored the gender dynamics of the antifascist campaign. Casting proletarian women as especially vulnerable, communists contrasted female defenselessness with Nazi brutality.

Despite the escalating violence in working-class districts in the early 1930s, the KPD's stance on violence was riddled with inconsistencies. Throughout 1931, the Central Committee repudiated acts of 'individual terror', insisting that the fight against fascism was 'not a physical fight but an ideological fight'. ${ }^{47}$ In other words, activists were to refrain from committing individual acts of violence; instead, they were to participate in 'proletarian mass terror' or mass action. On the ground, however, many activists pressed for a more militant strategy. Similar to rank-and-file social democrats who advocated an aggressive posture against Nazism, including armed struggle if necessary, communist antifascists generally endorsed a more aggressive response than KPD leaders. ${ }^{48}$ Cell papers, in particular, demanded militancy. Mocking a local sPD leader for instructing workers to stay in their homes when Nazis marched in the neighborhood, a cell paper from Lauter urged, '[T] he workers must not stay seated when their own property is being threatened or when their class comrades are being knocked down .... [S]mashing fascism is a cause for the entire working people.' The article concluded with a call to arms: 'Raise your bayonets'. ${ }^{49}$

\footnotetext{
45 'Vorgeschmack vom 3. Reich,' Sozialistische Republik, 6-7 August 1932.

46 Die Rote Fahne: Organ für alle Werktätigen (Mittweida) 10, no. 2 (14 August 1931).

47 'Kampfbund gegen Faschismus. II. Bezirksverbandkonferenz am 14. u. 15. Feb. 1931 in Hamburg,' 1931, SAPMO-BA: RY1 I 4/9/1.

48 On social democrats' militancy, see Harsch, German Social Democracy, 183-201.

49 'Kampf gegen den Faschismus,' Der Späher: Organ der Kommunistischen GemeindeFraktion in Lauter, no. 13 (March 1931).
} 
The Berlin Viehhof factory cell concurred: 'Only by actively fighting will the National Socialist hordes be knocked down. The best defense is attack. ${ }^{50}$

KPD leaders' inconclusive stance on the use of violence underscored the fact that the Party's overall antifascist strategy was mired in inconsistency and grave misjudgment. Guided by the Comintern's 'Third Period' doctrine, the KPD vacillated on the question of how to respond to Nazism. On the one hand, party leaders endorsed a militant response, encapsulated in the slogan 'Smash the fascists wherever you meet them!' On the other hand, leaders instructed activists to focus on propaganda activities. This lack of clarity rippled through the antifascist movement, for the strategic contradictions confused activists and prompted them to act in ways that made sense to them on the ground. ${ }^{51} \mathrm{~A}$ grassroots response to Nazism rooted in the everyday realities of working-class communities was reinforced by the fact that most antifascists remained outside the KPD and its organizations. ${ }^{2}$ While hundreds of thousands confronted Nazism, from marching in demonstrations, to participating in neighborhood defense, to quarreling with fascist neighbors, the overwhelming majority never joined the KPD or its antifascist organizations. ${ }^{53}$

\section{Political Culture and Political Conflicts}

Borrowing heavily from the KPD's repertoire of rituals, symbols, and languages, antifascists consistently deployed political culture to confront Nazism. The most public forum for communist antifascist culture was the open-air demonstration. In 1931 and 1932, antifascists held frequent marches that assembled thousands and sometimes tens of thousands of people. Funerals for the victims of political violence provided the consummate forums to showcase communist culture. In Cologne on 10 July 1932, for example, thousands of people

$50 \quad$ 'Kampf dem Faschismus!' Die Viehhof-Spritze: Betriebszeitung: Organ für die Interessen der Belegschaft des Städtischen Vieh-u Schlachthofes 4, no. 1 (January 1931).

$51 \quad$ See also Rosenhaft, Beating the Fascists? 94, 99, 142, 147; McElligott, Contested City, 181-182; Mallmann, Kommunisten, 374-38o; Swett, Neighbors and Enemies, 198-199; Ward, "Smash the Fascists...", 61.

In 1932, the Cologne KPD leadership reported that about one-half of the three thousand registered Fighting League members paid dues. 'Bericht über Instruktion und Kontrolle im Bez. Mr,' n.d. (c. August-November 1932), SAPMO-BA: RY1/I 3/21/15. In Altona, police estimated that seventy percent of the local Antifascist Action did not belong to a political party in July 1932. McElligott, Contested City, 170.

53 The KPD did enjoy an uptick in membership in 1931 and 1932 when the antifascist movement crested and party membership climbed to 287, ooo. Weber, Die Wandlung, vol. $1,362-364$. 
paraded in disciplined formation through the city. The march began on the street where Albert Wisnewsky had been murdered by Nazis two weeks earlier; it traversed through the working-class district until it reached Wisnewsky's home, which was draped in red flags. The local organ described the pageantry: 'The demonstration itself was carried by a momentous wave like we have seldom experienced. "Brüder, zur Sonne, zur Freiheit", sung from 25,00o throats, opened it.' Workers of various political stripes joined together, shouting 'Red Front' and 'Heil Moscow' with raised fists. 'A sea of red flags and banners were carried through the city ... Fighting songs were sung, and the entire mood of the parade actualized the will to fight, ... the will of the Antifascist Action.' In closing, the crowd sang The Internationale. ${ }^{54}$ As this description underscores, antifascist demonstrations were replete with symbolic practices: celebrants marching in lockstep, fighting songs, battle cries, raised fists, and thousands of red flags. These rites, however, were more than a collection of ritualistic practices designed to boost the KPD's public profile. They were militant practices that conveyed intransigent enmity to both Nazism and the Republic. ${ }^{55}$ Communist ritualistic practices stoked militancy and transformed activists into political soldiers who were willing to don antifascist emblems and to defend their turf.

Operating in the same political space that reviled parliamentary democracy, the NSDAP developed a culture that was equally provocative. ${ }^{56}$ Communists documented the growing presence of Nazi ritualistic practices in proletarian districts and the ways they escalated tensions. While political battles on cultural terrains were hardly novel in the early 1930s, the extent to which ritualistic practices engendered violence was indeed new. What distinguished late Weimar from other epochs was the dramatic, even deadly, competition over political symbols, for Weimar's street violence included a war of symbols between political opponents who fought daily over flags, insignia, battle cries, and songs.

54 'Das Kampfgelöbnis der 2500o!' Sozialistische Republik, 11 July 1932; '250oo Antifaschisten,' Sozialistische Republik, 11 July 1932; 'Kundgebung der Einheitsfront,' Sozialistische Republik, 11 July 1932.

Gottfried Korff, 'Rote Fahnen und geballte Faust: Zur Symbolik der Arbeiterbewegung in der Weimarer Republik,' in Transformation der Arbeiterkultur, Deutsche Gesellschaft für Volkskunde: Kommission Arbeiterkultur. Arbeitstagung 1985, ed. Peter Assion (Marburg: Jonas, 1986), 137-148.

56 Jay W. Baird, To Die for Germany: Heroes in the Nazi Pantheon (Bloomington: Indiana UP, 199o); Ulrich Herrmann and Ulrich Nassen, ed., Formative Ästhetik im Nationalsozialismus (Weinheim: Beltz, 1994); Gerhard Paul, Aufstand der Bilder: Die NS-Propaganda vor 1933 (Bonn: Dietz, 199o); Reichardt, Faschistische Kampfbünde. 
Communist political culture served a number of critical functions. First, it was designed to cultivate loyalty. According to Guy Debord, the 'spectacle' serves as a device of social control that propagates a moral order. ${ }^{57}$ With activists partaking in collective rituals, antifascist culture integrated followers into the KPD fold, scripting celebrants to commit themselves to struggle on the public rostrum. Second, communist culture was deployed to forge an esprit de corps among antifascists. Scholars have long noted the importance of collective rites in the cultivation of solidarity. ${ }^{58}$ For communists, collective rites prompted activists to perform antifascist fraternity. Third, communist cultural practices were choreographed to fuel militancy. Ritualistic practices, as Arnold van Gennep asserts, are instrumental in effecting the personal conversions of celebrants. ${ }^{59}$ Communist symbolic practices had the capacity to move activists to action, to transform them into warriors. Finally, by cultivating shared mental grids', political cultures shape celebrants' beliefs, as Mabel Berezin theorizes. ${ }^{60}$ With each repetition of a symbolic gesture, antifascists reaffirmed their commitment to the communist moral order. The compounding impact of the repeated performances influenced participants' consciousness, as celebrants learned the language of antifascism and internalized the semiotic repertoire to such a degree that they modified both their personal behavior to conform to the style of communism and their personal beliefs to adhere to tenets that undergirded the political culture. One outcome of this disciplining process was that celebrants transferred communist symbolic practices from official demonstrations to their neighborhoods to address the challenges they faced every day. ${ }^{61}$

Among the most potent symbols in the communist cultural arsenal was the antifascist flag. As seen in figure 1, the KPD created a red flag with antifascist insignia upon it as the Antifascist Action's foundational emblem. Published on the front page of Die Rote Fahne during the height of Weimar's political violence

57 Guy Debord, Society of the Spectacle (Detroit: Black \& Red, 2010), thesis 4.

58 Émile Durkheim, Elementary Forms of the Religious Life (Mineola, NY: Dover Publications, 2008), esp. 427-428.

59 Arnold Van Gennep, The Rites of Passage (Chicago: Chicago University Press, 1969), 10-15.

6o Mabel Berezin, 'Politics and Culture: A Less Fissured Terrain,' Annual Review of Sociology 23 (1997): 361-383, esp. 368.

$61 \quad$ On the self-disciplining process in communist movements, see Tim Rees, 'Deviation and Discipline: Anti-Trotskyism, Bolshevization and the Spanish Communist Party, 192434, Historical Research 82, no. 215 (2009): 131-156; Randi Storch, “The Realities of the Situation": Revolutionary Discipline and Everyday Political Life in Chicago's Communist Party, 1928-1935,' Labor Studies in Working-Class History of the Americas 1, no. 3 (2004): 19-44. 


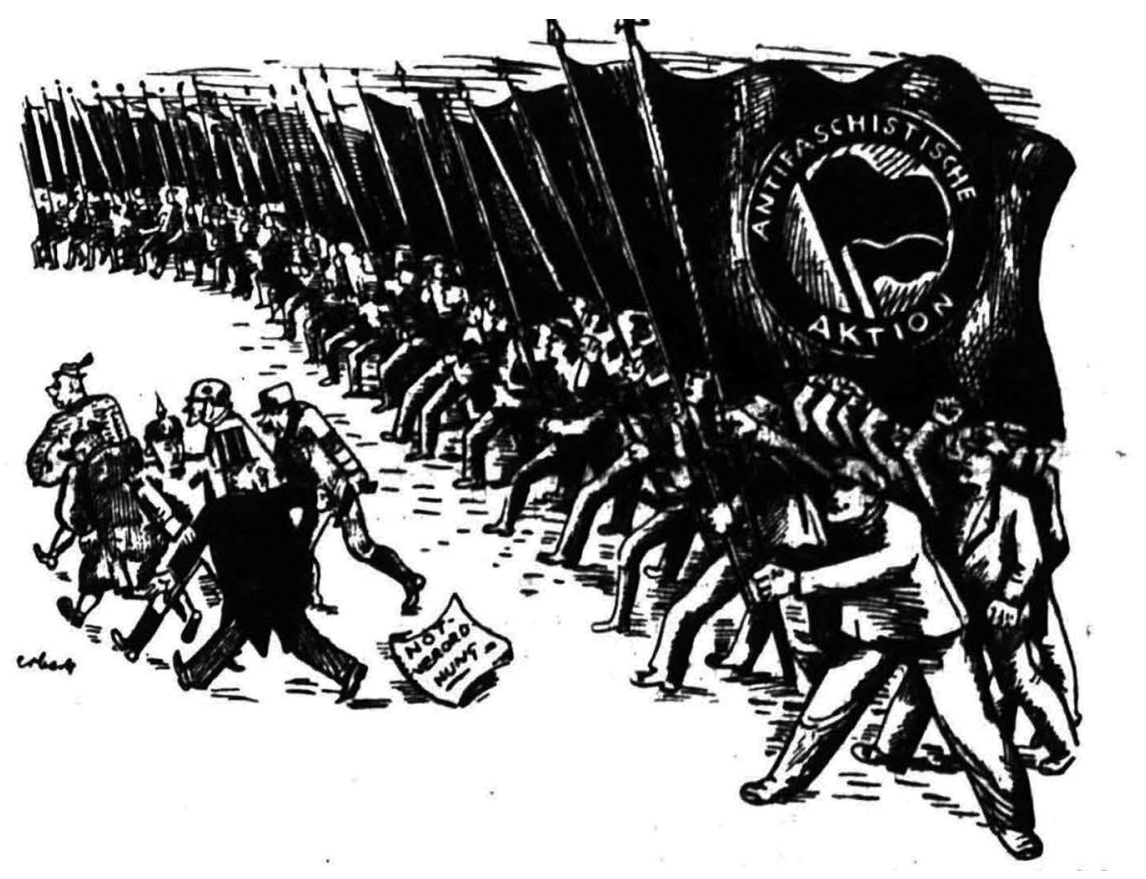

FIGURE 1 Antifascist Action Flag, Die Rote Fahne, 3 July 1932, front page.

in July 1932, this sketch features a parade of men wielding Antifascist Action flags as they chase down fascists and their allies, who run in fear, dropping an emergency decree. The men, marching shoulder to shoulder, are depicted as audacious warriors. That many carry an Antifascist Action flag reinforces both their militancy and unbreakable solidarity.

In the early 1930s, the communist antifascist flag was ubiquitous in Germany's streets. Describing how most residents in Cologne-South hung flags from their apartments, one communist explained the flag's power: 'Everyone sees how many there are in the fight against fascism. They feel stronger .... Every red flag says: Here lives an antifascist, a revolutionary proletariat. ${ }^{\prime 2}$ Given that the flag conveyed unambiguous opposition to Nazism, it was at the root of considerable conflict. ${ }^{63}$ National Socialists understood the combative and proprietary connotations inscribed in the antifascist flag. Recounting a stabbing of a young man by SA men in September 1932, one worker correspondent testified

62 'Rote Fahnen heraus!' Sozialistische Republik, 28 July 1932.
63 Schumann, Political Violence, 253-255. 
that the flag catalyzed conflict. The Nazis allegedly threatened, '[Cologne] Mülheim is now going to be cleared out. You won't be hanging any more red flags outside!'64 In another article, a Hamburg cell paper reported that Nazi Youths marched into a proletarian district and destroyed several flags on election day in September 1930, which instigated a physical confrontation with antifascists. ${ }^{65}$

Political music was another common source of conflict between communists and Nazis, for both groups regularly marched through working-class boroughs singing political songs, especially after meetings or rallies. ${ }^{66}$ Singing on both sides was the cause of continual conflict. While antifascists mobilized to check the Nazis' singing, Nazis similarly challenged antifascist singing. Typical of such clashes was a song battle at a 1931 Nazi meeting in Oberlahr, as recounted by a worker correspondent. As a Nazi took to the podium, 'The Internationale roared through the hall! Nazis responded with a rendition of the Deutschlandlied, but the 'revolutionary workforce' rebutted with The Internationale. Suddenly, the meeting erupted into a mêlée. ${ }^{67}$ In this instance, not only did communists deploy The Internationale to goad the Nazis, but more importantly, the antifascists' singing ignited the violence, an outcome that was hardly surprising to anyone present. In another incident, a worker correspondent reported that two SA men spent an entire day in Cologne-Kalk singing 'Nazi death songs' and wielding pistols. According to the author, neighbors retorted with The Internationale, which led to a brawl that culminated in the defenestration of the Nazis. ${ }^{68}$

For communists, recitations of Nazi battle cries and salutations were particularly alarming. Both activists and the KPD press frequently reported that Nazis traversed city streets, yelling slogans, such as 'For every Red, a death!'

64 Worker Correspondent, 'sA-Strolche überfallen Jungarbeiter,' Sozialistische Republik, 11 September 1932 .

65 'Der 14 September 1930,' Der Valvo-Funke: Betriebszeitung der Belegschaft Valvo (Hamburg), January 1931.

66 On political music during the Weimar Republic, see Richard Harold Bodek, 'Red Song: Social Democratic Music and Radicalism at the End of the Weimar Republic', Central European History 28, no. 2 (1995), 209-227; John Eckhard, Musik-Bolschewismus: Die Politisierung der Musik in Deutschland 1918-1938 (Stuttgart: Metzler, 1994); Vernon Lidtke, 'Songs and Nazis: Political Music and Social Change in Twentieth-Century Germany,' in Essays on Culture and Society in Modern Germany, ed. Gary D. Stark and Bede Karl Lackner (College Station: University of Texas, 1982), 167-200.

67 Worker Correspondent 165, 'Nationalfaschistische Niederlage in Oberlahr,' Sozialistische Republik, 19 February 1931.

68 Worker Correspondent, 'Nazi-Provokateure in Kalk,' Sozialistische Republik, 15 July 1932. 
and 'Heil Hitler!' ${ }^{9}$ As one worker correspondent recounted, the Nazis woke up the entire neighborhood with a 'Howl-Hitler cat concert'.70 During such ritualistic actions, Nazis allegedly approached passersby and ordered them to salute. Such incidents usually concluded only with threats, but on some occasions, the confrontations spiraled into combat, particularly when the target responded with 'Red Front!' In short, battle cries either sparked or accompanied conflict, as shouting matches between fascists and antifascists were often preludes to physical confrontation.

In an atmosphere of extreme political volatility, uniforms were especially inflammatory, which is why government officials periodically banned both communist and Nazi clothing in the final years of the Republic. Communists viewed National Socialist insignia as particularly menacing, especially when sA men donned it collectively.71 One worker correspondent wrote, 'In the light of day', Nazis walk around without uniforms, appearing 'civil', but in the dark of night, they are decked out in their uniforms. ${ }^{72}$ The sinister reading of the Nazi uniform was on prominent display in Berlin's Dunker Street after someone nailed a Nazi uniform to a wall and wrote in eighteen-meter-tall letters: 'This is the uniform of the killers of workers.'73

Communists also sported incendiary insignia. Mindful of workers' deteriorating economic status with the onset of the Depression, the KPD created affordable emblems that could be affixed to one's clothing and worn by the maximum number of people. Among the most popular was the Antifascist Action badge, typically worn by men on their caps. ${ }^{74}$ Identifying wearers as communist, antifascist insignia regularly stoked conflict. ${ }^{75}$ According to activists, Nazis saw the antifascist badge as especially provocative, and they frequently assaulted those wearing the emblem. ${ }^{76}$

69 Worker Correspondent 814, 'Für jeden Toten einen Roten,' Sozialistische Republik, 3 December 1931; 'Nazi Blutbad im Rheinland,' Adam-Opel-Prolet: Betriebszeitung der Opelwerke (Rüsselheim) 4, no. 22 (December 1930).

70 Worker Correspondent 520, '30 Rassemenschen blamieren sich in Lindenthal,' Sozialistische Republik, 8 August 1931.

$71 \quad$ 'Arbeiter stellen bewaffneten Nazi', Sozialistische Republik, 22 June 1932.

72 'Hitlerbande überfällt katholische Jugend,' Sozialistische Republik, 21 July 1932.

73 'Notverordnungs-Uniform an die Wand genagelt,' Die Rote Fahne, 7 July $193^{2}$.

74 'Organisationsrichtlinien für die Aufbau und die Aufgabe.; 'Richtlinien zur Schaffung der Antifaschistischen Aktion.'

75 Schumann, Political Violence, 187.

76 'Nazis stechen Arbeiter nieder', Sozialistische Republik, 6 July 1932; 'Hitlerbande überfällt katholische Jugend,' Sozialistische Republik, 21 July 1932. 
Nazi and communist political cultures were at the center of considerable conflict, as both sides deployed symbols and rituals to cultivate fraternity among their comrades and to express their political views. These ritualistic practices also fomented confrontation, including violent clashes. Particularly when deployed in neighborhoods, these political cultures contributed decisively to the mounting tensions that pervaded working-class communities in the early 1930 .

\section{The Gender Politics of the Communist Antifascist Movement}

While the overwhelming majority of stories of political violence detailed fracases between men, there is a significant body of sources that testified to the violence that women also faced. To be sure, women were among the victims of the violence, and the violence against them increased in 1932 amid the rising violence more generally. ${ }^{77}$ In some cases, women encountered violence as they engaged in political work. For example, the KPD press reported that twenty couples were attacked by Nazis while conducting propaganda work in Worms in November 1932. One woman and her husband were even allegedly thrown out of a window. ${ }^{78}$ Other times, women fell victim due to being in the wrong place at the wrong time, as seemed to be case with a 63-year-old cleaning woman whom Nazis shot near the Görlitzer train station in Berlin in July $1932 .{ }^{79}$ Such accounts underscored that women were caught up in the street politics. Whether as victims, political organizers, or warriors, women figured prominently in the daily confrontations with Nazis.

When the KPD founded its antifascist movement, leaders welcomed women and directed the cadre to recruit them. 'Working women and girls belong in

77 Other than noting the predominance of male antagonists, the first wave of scholarship on Weimar's political violence largely overlooked gender relations. More recently, historians have investigated the decidedly masculine tenor of the violence, focusing particularly on militaristic models and militant rituals, which were pervasive among both rightwing and left-wing fighting units. See Joachim C. Häberlen, "'Weiter haben sich zwei Frauenpersonen besonders hervorgetan": Zur Rolle von Frauen in der Straßenpolitik am Ende der Weimarer Republik,' Homme: Zeitschrift für Feministische Geschichtswissenschaft 23, no. 1 (2012): 91-105; Schumann, Political Violence, 186-206; Sara Ann Sewell, 'The Party Does Indeed Fight Like a Man: The Construction of a Masculine Ideal in the Weimar Communist Party,' in Weimar Culture Revisited, ed. John A. Williams (New York: Palgrave, 2011), 161-182.

78 'Einheitsfront gegen die Nazi-Partei', Sozialistische Republik, 26 November 1931.

79 'Vier neue Blutopfer der SA-Horden,' Die Rote Fahne, 5 July 1932. 
our ranks as active female fighters', the Fighting League declared. ${ }^{80}$ Such calls echoed the KPD's general position on organizing women that 'women cannot be excluded from any proletarian organization. ${ }^{81}$ Among the most enthusiastic antifascists were members of the Roter Frauen- und Mädchen Bund [R Fм в; Red Women and Girl's League]. Founded in 1925 to attract to a broad female working-class constituency to the KPD, the RFMB sought to recruit women by politicizing issues they faced in their daily lives, such as wages, welfare, and reproductive rights. ${ }^{82}$ Shortly after the Fighting League's establishment, the RFM B was reorganized under the League's auspices. It even added the subtitle Organ of the Antifascist Women's Movement to its paper, Frauenwacht, rebranding it as the KPD's antifascist paper for women. ${ }^{83}$

With the founding of its antifascist movement, the KPD called on women to prepare for battle. In fact, both the Fighting League and the в Fм в instructed women to take up military training. ${ }^{84}$ On the ground, many agreed that women should serve as frontline soldiers, as conveyed in figure 2 from a Kiel neighborhood cell paper. Towering over two Nazis, this female figure is positioned squarely on the battlefield. She is portrayed as strong, committed to struggle, and battle-ready. The RFMB regularly published similar images, showing women in militaristic garb and wielding weapons. ${ }^{85}$ Such depictions suggest that many communists cultivated female antifascist militancy.

The recruitment of women as antifascist soldiers was not merely propaganda, however, for many women fought directly on the frontlines. Oftentimes, women battled alongside their male comrades. For example, Die Rote Fahne

80 'Kampfbund gegen Faschismus. II. Bezirksverbandkonferenz am 14. u. 15. Feb. 1931 in Hamburg.'

81 'Bericht über die Verhandlungen des 10. Parteitages der KPD (Sektion der KI), Berlin vom 12. bis 17. Juli 1925,' (Berlin, 1926), 764. See also Hans-Jürgen Arendt and Werner Freigang, 'Der Rote Frauen- und Mädchenbund: Die revolutionäre Frauenorganisation in der Weimarer Republik, Beiträge zur Geschichte der Arbeiterbewegung 21 (1979): 249-58.

On the RFMB, see Hans-Jürgen Arendt and Werner Freigang, 'Der Rote Frauen- und Mädchenbund: Die revolutionäre Frauenorganisation in der Weimarer Republik,' Beiträge zur Geschichte der Arbeiterbewegung 21 (1979): 249-258; Sara Ann Sewell, 'Bolshevizing Communist Women: The Red Women and Girls' League in Weimar Germany,' Central European History 45, no. 2 (2012): 268-305.

83 B.V.L. Thüringen, 'Rundschreiben No. 6,' Erfurt, 29 June 1932, SAPмO-BA, RY1 I 4/9/4; Arendt and Freigang, 'Der Rote Frauen- und Mädchenbund,' 257.

84 'Richtlinien für die Arbeit der Frauen und Mädchenstaffeln des Kampfbundes gegen den Faschismus,' n.d. (c. 1931/32), SAPMO-BA: RY1 I 4/9/4; 'Bericht der Reichsfrauenleitung des Kampfbundes gegen den Faschismus,' n.d. (c. 1932), SAPMO-BA: RY1 I 4/9/3.

85 RFM B flyer 'Military preparedness of the working women for class struggle,' (c. 1930), SAPMO-BA: RY1 I 2/8/66; Die Fanfare: Kampforgane des Faschismus, February 1932. 


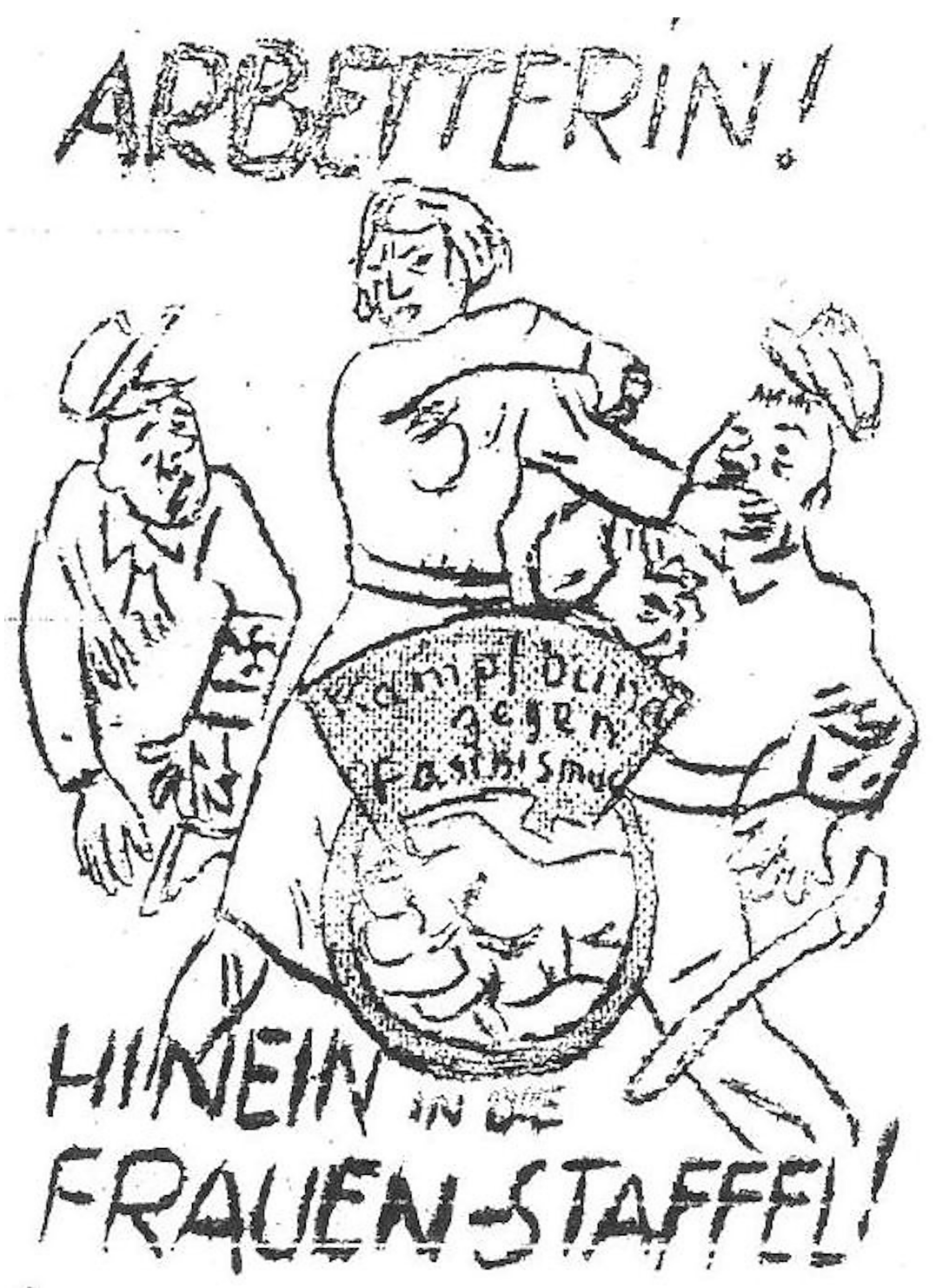

FIGURE 2 Fighting League against Fascism Female Fighter. Caption: 'Working women into the Women's Squadron,' Das Hinterhaus, Kiel, March 1931.

recounted how women and their husbands clashed with Nazis in Franzburg in July 1932. The paper quoted one participant: 'We were not going to stand by and do nothing or run away when we saw that these beasts wanted to kill our husbands. ${ }^{86}$ Other reports documented women fighting alone, such as in 1930

86 'Wir werden doch nichtmüßig beiseitestehen,' Die Rote Fahne, 10 July 1932. 
when a RFM B drum corps, traveling to Elmshorn for a rally, brawled with Nazis. According to an internal report, when the Nazis saw the women bedecked in RFM B gear, tensions quickly rose and a battle ensued. ${ }^{87}$ That women were antifascist fighters was borne out by court statistics as well. For example, in August and September 1932, 23 women were incarcerated for political violence. ${ }^{88}$

Despite the KPD's call for women to engage in struggle, some male activists staunchly rejected women as frontline soldiers. On the ground, many activists believed that women should serve exclusively as propagandists: they should convene women's meetings, sell literature, host singing evenings, and sew banners. ${ }^{89}$ The Rғмв summarized this perspective: 'From the beginning, we had to overcome significant resistance among male comrades who ... took the position that women have nothing to seek in a military organization. ${ }^{\prime 90}$ Internal reports confirmed this assessment. For example, some Fighting League members threatened to quit the organization if women formed combat units; others even blocked doors to prevent women from entering meetings. ${ }^{91} \mathrm{KPD}$ leaders responded by repeatedly reprimanding male comrades, as in the following directive: 'The fight against fascism is not a thing only for men .... Every local group, every squadron, is obligated to accept the organization of women and girls immediately ... Whoever refuses or sabotages this work has no place in our ranks. ${ }^{92}$ But party leaders made little headway in changing deeply entrenched antifeminist views. ${ }^{93}$

Communist men's refusal to accept women as equal comrades was not simply evidence of resistance to party directives, for the KPD, itself, did not always prioritize the organization of women. Indeed, other than issuing pronouncements of gender equality and setting up separate women's organizations,

87 Johanna Piiper, Die Frauenpolitik in der KPD in Hamburg 1928 bis 1933 (Cologne: PahlRugenstein, 1988), 62.

88 Arendt, 'Zur Frauenpolitik der KPD,' 818.

89 'Bericht der Reichsfrauenleitung des Kampfbundes gegen den Faschismus,' n.d. (c. 1931), SAPMO-BA: RY1 I 4/9/3; 'Richtlinien für die Arbeit der Frauen und Mädchenstaffeln des Kampfbundes gegen den Faschismus,' (c. 1931/32).

90 'Bericht der Reichsfrauenleitung des Kampfbundes', (c. 1931).

$91 \quad$ Ibid.

92 Alarm: Mitteilungsblatt für die Funktionäre des Kampfbundes gegen den Faschismus, February 1931.

93 'Kampfbund gegen Faschismus. II. Bezirksverbandkonferenz am 14. u. 15. Feb. 1931 in Hamburg.; 'Bericht und Resolutionen, 1. Reichsführer-Tagung, 4.15, Berlin, Alarm: Mitteilungsblatt für die Funktionäre des Kampfbundes gegen den Faschismus, April 1931, SAPMO-BA, RY1 I 4/9/5; Gewinn die Betriebsarbeiterinnen für die antifaschistische Front!' Alarm: Mitteilungsblatt für die Funktionäre des Kampfbundes gegen den Faschismus, January 1932, SAPMO-BA: RY1 I 4/9/5. 
the KPD brass never fully committed itself to gender equality. That Rosa Luxemburg, Ruth Fischer, and Clara Zetkin stood at the highest echelons of the KPD should not overshadow the fact that women's presence at all ranks in the Party was marginal. ${ }^{94}$ As Silvia Kontos concludes, the KPD fought 'like a man'.95 Especially notable in this regard was the RFB's expulsion of its political sisters in May 1925, charging that women were physically unfit, susceptible to nervous disorders, and psychologically unsuited for military operations. ${ }^{96}$ Thus, while the KPD ostensibly welcomed women to both the Party and its ancillary organizations, male members at all levels largely relegated women to the status of adjunct revolutionary. This was replicated in the Fighting League, whose female membership ranged from ten to fifteen percent nationally. ${ }^{97}$ That women played a subordinate role in the antifascist movement was demonstrated in Thuringia where the local leadership, under financial duress, sent organizational materials only to men in $1932 .{ }^{98}$

Communist men's antifeminism grew more pronounced in the final years of the Weimar Republic when they trumpeted a militant masculinity in the face of a political opponent that threatened their core beliefs and a cataclysmic economic crisis that challenged their role as provider. As Karen Hagemann asserts, many working-class men 'sought to create "women-free" spaces in the political arena' as a self-preservation strategy. ${ }^{99}$ Contributing decisively to the antifeminist views was the belief that the struggle against Nazism, particularly as it played out in their backyards, was a test of masculinity, for confrontations with Nazis provided antifascist men with forums to flex their revolutionary muscles. By the early 1930s, communists had constructed a masculine

94 KPD female membership remained consistent at fifteen percent. Hans-Jürgen Arendt, 'Weibliche Mitglieder der KPD in der Weimarer Republik: Zahlenmäßige Stärke und soziale Stellung,' Beiträge zur Geschichte der Arbeiterbewegung 19, no. 4 (1997): 654. Women represented less than twenty percent of the KPD electorate. Julia Sneeringer, Winning Women's Votes: Propaganda and Politics in Weimar Germany (Chapel Hill: University of North Carolina Press, 2002), esp. 99-106, 155-158.

95 Silvia Kontos, Die Partei kämpft wie ein Mann: Frauenpolitik der KPD in der Weimarer Republik (Frankfurt/M: Roter Stern, 1979).

96 'Betrifft Frauen und Mädelfrage und Berliner Roter Frontkämpferbund am 21. Mai,' 9 May 1925, SAPMO-BA: RY1/I 4/3/1; 'Bericht des Roten Frauen- und Mädchen-Bundes,' SAPMOBA: RY1/I 2/707/31.

'Bericht der Reichsfrauenleitung des Kampfbundes,' (c. 1931); 'Bericht der Reichsfrauenleitung des Kampfbundes,' (c. 1932).

$98 \quad$ Thüringen, 'Rundschreiben No. 6.'

99 Karen Hagemann, 'Men's Demonstrations and Women's Protest: Gender in Collective Action in the Urban Working-Class Milieu during the Weimar Republic,' Gender History 5 , no. 1 (1993): 101-119. 


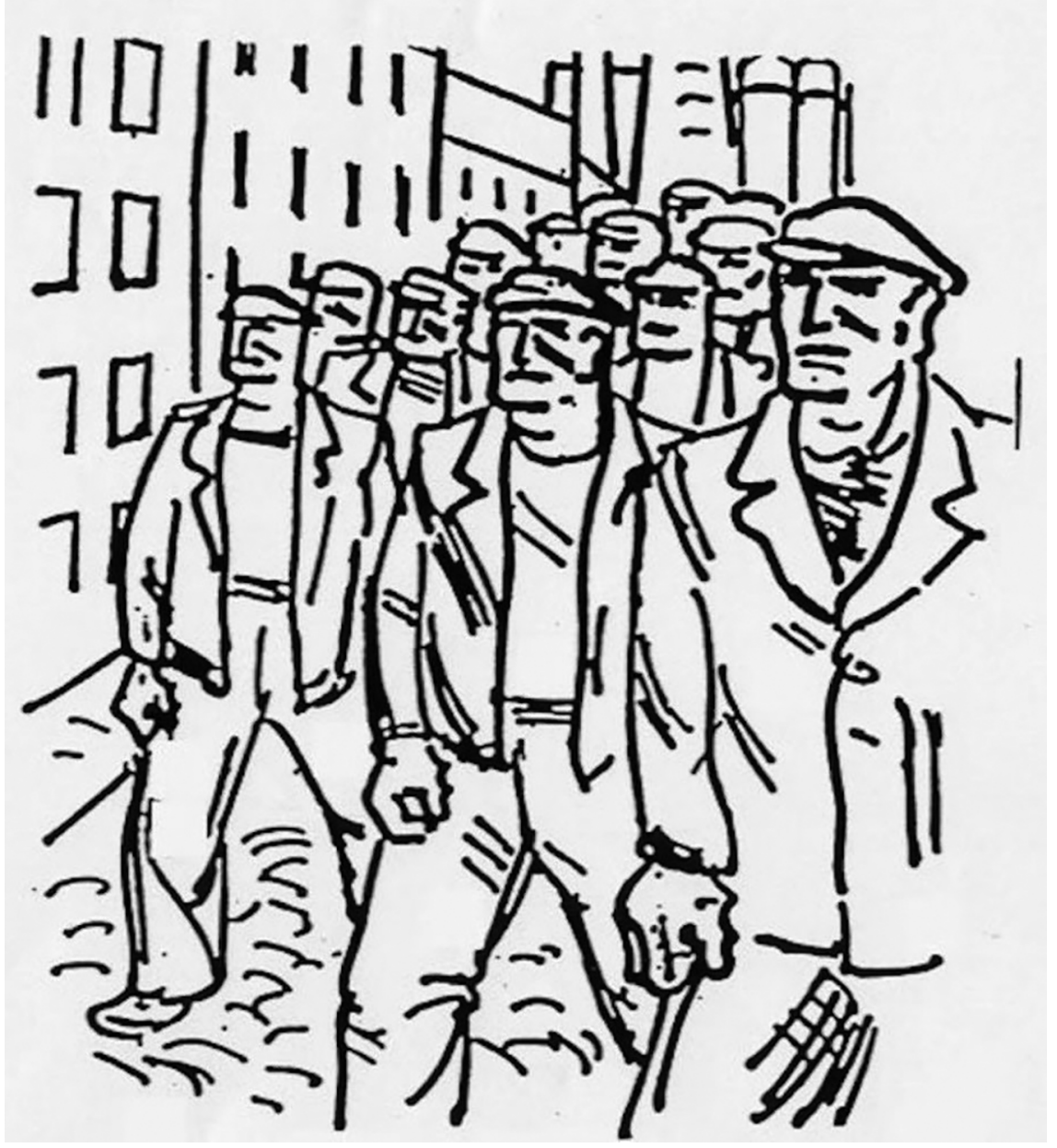

FIGURE 3 Kampferfahrungen, September 1932, front page.

archetype who earned his battle stripes by fighting fascists. ${ }^{100}$ In this context, the KPD advanced a visual lexicon that glorified hypermasculinity, as depicted in figure 3 .

This drawing offers a common communist depiction of revolutionary fighters in the final years of the Republic. As they seize the streets, the men, uniformly dressed in working-class garb, prepare for confrontation. They wear an expression of grim determination, marching in closed ranks from the factory. Their fists tightly clenched, their square jaws jutting forward, they project an

100 See Mallmann, Kommunisten, 138-141; Sewell, 'The Party Does Indeed Fight Like a Man,' in passim; Weitz, Creating German Communism, 188-232. 


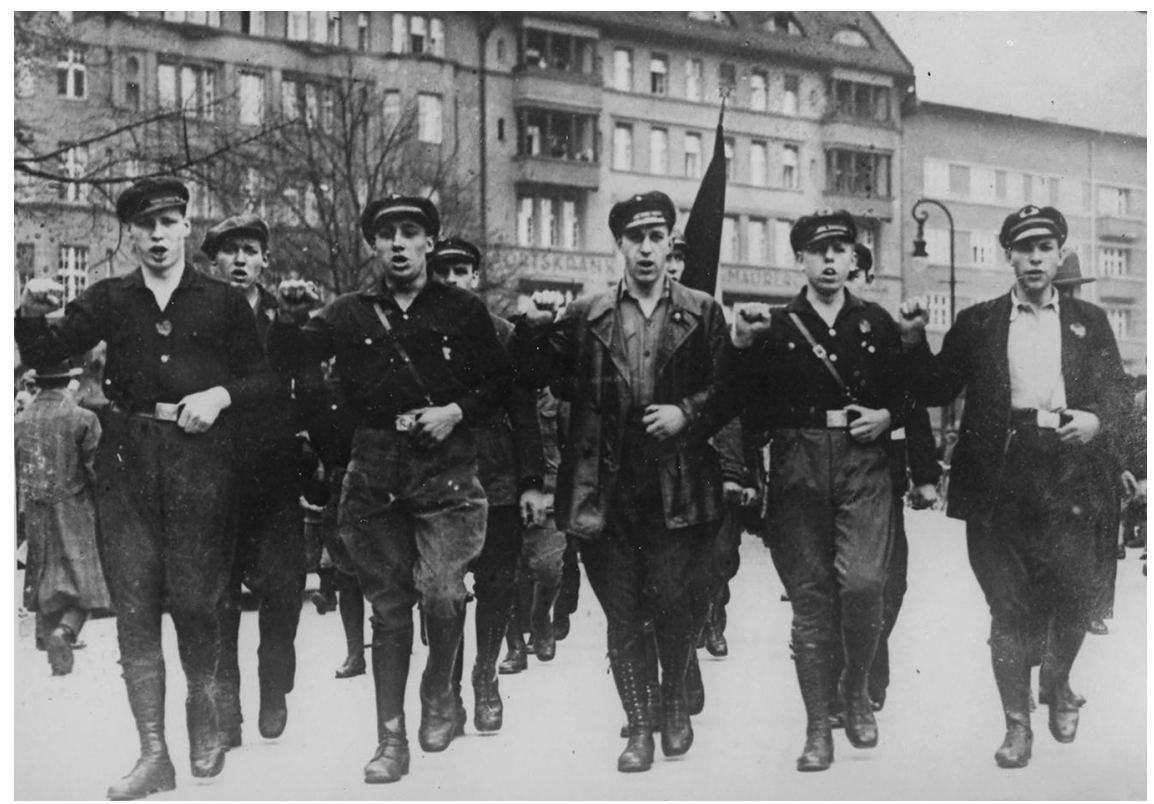

FIGURE 4 Antifascist men demonstrating in Berlin on Bülowplatz, 1 May 1931. Source: Stiftung Archiv der Parteien und Massenorganisationen der ehemaligen DDR im Bundesarchiv (SAPMO-BA), Berlin, Zentrales Parteiarchiv, Bild Y1-11838.

unmistakable image of militant masculinity. Such militancy was replicated on the streets, as seen in figure 4, which is a photograph from the 1931 May Day demonstration in Berlin. Marching and singing in martial formation with raised fists, the men convey political resolve in imagery that strikingly mirrors the previous illustration. From their caps to their jackboots, these fierce communists are ready for battle. They personify communist antifascist masculinity.

\section{Conclusion}

When the KPD launched its antifascist movement, it set out to establish a movement composed of workers of all political stripes. Clearly, communists failed not only to build a mass movement, but more importantly, to defeat Nazism. Numerous factors contributed to their failure. Foremost was the fact that the NSDAP was on the march with the support of many Germans who perceived communists to be a greater threat than Nazis. Contributing to communists' political failure was also the KPD's confounding antifascist strategy. Nevertheless, hundreds of thousands of activists mobilized to challenge Nazism. While the Reichstag set the stage for high politics, it was the 
working-class neighborhood that provided the forum for citizens to express their views.

In the early 1930s, proletarian districts were the scenes of the most acute political expression, violence. Political violence intensified in 1932, claiming someone's life nearly every week, if not every day. While violence stood at the center of struggle, political conflict was more pervasive than measured only by acts of violence. Indeed, in working-class communities throughout Germany, neighbors clashed over a host of issues, including the mundane matters of everyday life. In the context of rising tensions, communists sought to radicalize their neighbors by politicizing ordinary quarrels. Everyday arguments were increasingly colored with political narratives, which antifascists exploited. In no small measure did the KPD's and NSDAP's symbolic repertoires contribute to this radicalization, particularly when one side sought to conquer spaces symbolically with political emblems that staked out territory.

Few, if anyone, could escape the mounting tensions. Therefore, women joined men in the struggle, from sewing banners, to conducting neighborhood surveillance, to marching in demonstrations. Some women also battled Nazis to the dismay of many communist men who insisted that combat was exclusively a masculine political charge. Parading a militant hypermasculinity in the face of a lethal adversary, many men blocked their political sisters from the frontlines of struggle. 